Bulletin of the Seismological Society of America. Vol. 55, No. 1, pp. 165-180. February, 1965

\title{
FAULT MOTIONS AT THE BALDWIN HILLS RESERVOIR SITE
}

\author{
By Donald E. Hudson and Ronald F. Scott
}

\begin{abstract}
A distinction is made between the damaging potential of rapid fault motions associated with earthquakes and those having a relatively slow creep type motion. Information is given on nonseismic movements that have been occurring on faults passing through the Baldwin Hills Reservoir during the past 10 years. The relationship between those faults and the Inglewood fault system is described, and correlations are presented with local elevation changes, horizontal ground movements, and seismic activity. Comparisons are made with similar slow fault motions occurring at other places in California, and attention is drawn to the potential damaging effects of such movements.
\end{abstract}

\section{INTRODUCTION}

Fault movements may damage man-made structures through two different kinds of action. Rapid fault motions may generate seismic waves which can cause ground shaking at considerable distances from the fault. This ground shaking may then in turn cause damaging inertia forces in structures, or it may result in foundation deformations which can lead to structural failure. Both of these types of damage are usually referred to as "earthquake damage", and it is the aim of earthquakeresistant design to minimize the destructive effects of these rapid fault motions by economic means.

There is another type of fault motion which can also cause damage. There have been several instances in recent years of fault motions that have occurred so slowly that no seismic activity was generated, and which were so located with respect to engineering structures that the fault movements themselves caused damaging deformations of the structure. This second kind of damage is clearly directly associated with fault motions, and yet it is not in any sense earthquake damage. Although slow fault motion may not be as spectacular a phenomenon as a large earthquake, the potential damage may be as great, and studies are needed to develop the best way of coping with such situations.

The most recent example of a non-seismic fault motion which caused structural damage is that associated with the failure of the Baldwin Hills Reservoir in the City of Los Angeles, on December 14, 1963. This event is discussed in detail in a comprehensive report issued by the State of California Department of Water Resources ("State Report", 1964). The object of the present paper is to describe certain features of the fault movements that occurred at Baldwin Hills, and to compare them with several other cases which have been reported in other parts of California. It seems clear that as the various tectonically active and heavily faulted regions of the world become more and more occupied with people and engineering structures, damage of this kind can be expected to become more common, and special design techniques must be developed to avoid it.

\section{Geology of the Fault Area}

The Baldwin Hills Reservoir site is in the Inglewood Fault Zone, a few hundred feet northeast of the surface trace of the main fault, in a region of considerable 
recent tectonic activity. (Driver, 1943; Woodford, et al., 1954; Castle, 1960). Along this Inglewood Fault Zone originated two notable earthquakes, in 1920 and 1933, the second being the well-known destructive Long Beach earthquake.

A vertical cross-section through the fault zone and the reservoir, at right angles to the major trend of the fault is shown in fig. 1 (State Report, 1964). This is a schematic diagram which merely aims to indicate the main features of the situation. These major features are also shown in fig. 2, where the surface fault traces have been taken from a recent map prepared by Castle for the U.S. Geological Survey

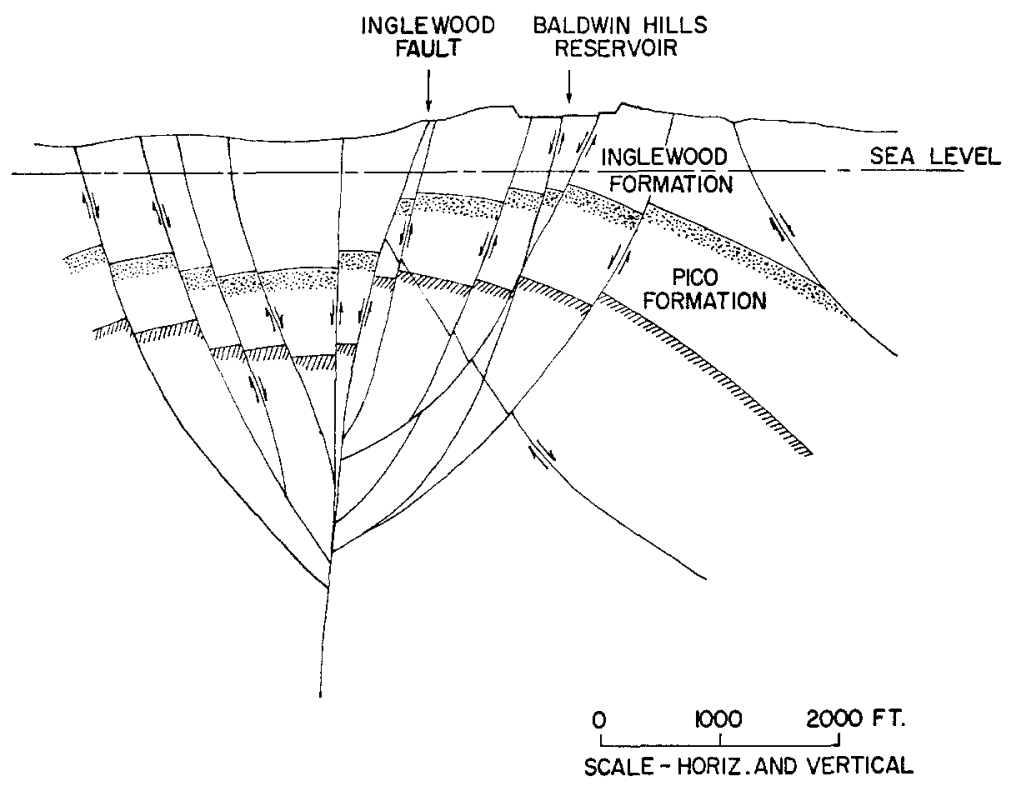

FIG. I SCHEMATIC DIAGRAM OF INGLEWOOD FAULT SYSTEM AT THE BALDWIN HILLS RESERVOIR (APPROX.TO SCALE - REF. STATE REPORT, 1964)

(Castle, 1960). Although geologic investigations have indicated that the total displacements on the fault zone in this region are of the order of $250 \mathrm{ft}$ vertically and $1500 \mathrm{ft}$ laterally, there is no evidence of geologically recent lateral movements, such as offset streams (Driver, 1943; State Report, 1964).

The geologic section at the reservoir site may be briefly summarized as follows: (Wilson, 1949)

(a) Soil mantle, 2-3 ft, clayey silt with humus and some sand and gravel.

(b) Recent alluvium, several feet, mixture of clay, silt, sand and gravel.

(c) Palos Verdes formation, upper Pleistocene, about $60 \mathrm{ft}$ thick. Fine to coarse sands interbedded with sands and gravels, occasional beds of silt up to $1 \mathrm{ft}$ thick, loosely consolidated with a few beds of soft sandstone, 3-6 in. thick.

(d) Inglewood formation, lower Pleistocene, $100 \mathrm{ft}$ thick, fine sands, silts, and clays interbedded. 1 in. beds of limestone, $1 \mathrm{in}$. to $4 \mathrm{ft}$ sand and silt beds, 2 in. clay beds. 
(e) Pico formation, upper Pliocene, $1700 \mathrm{ft}$ thick, silt, with very fine sand and clay. $4 \mathrm{ft}$ beds of sandy silt and $1 \frac{1}{2} \mathrm{ft}$ beds of silty clay. Soft siltstone beds. All bedding planes are approximately horizontal.

The main embankment constructed at the north end of the reservoir is in contact

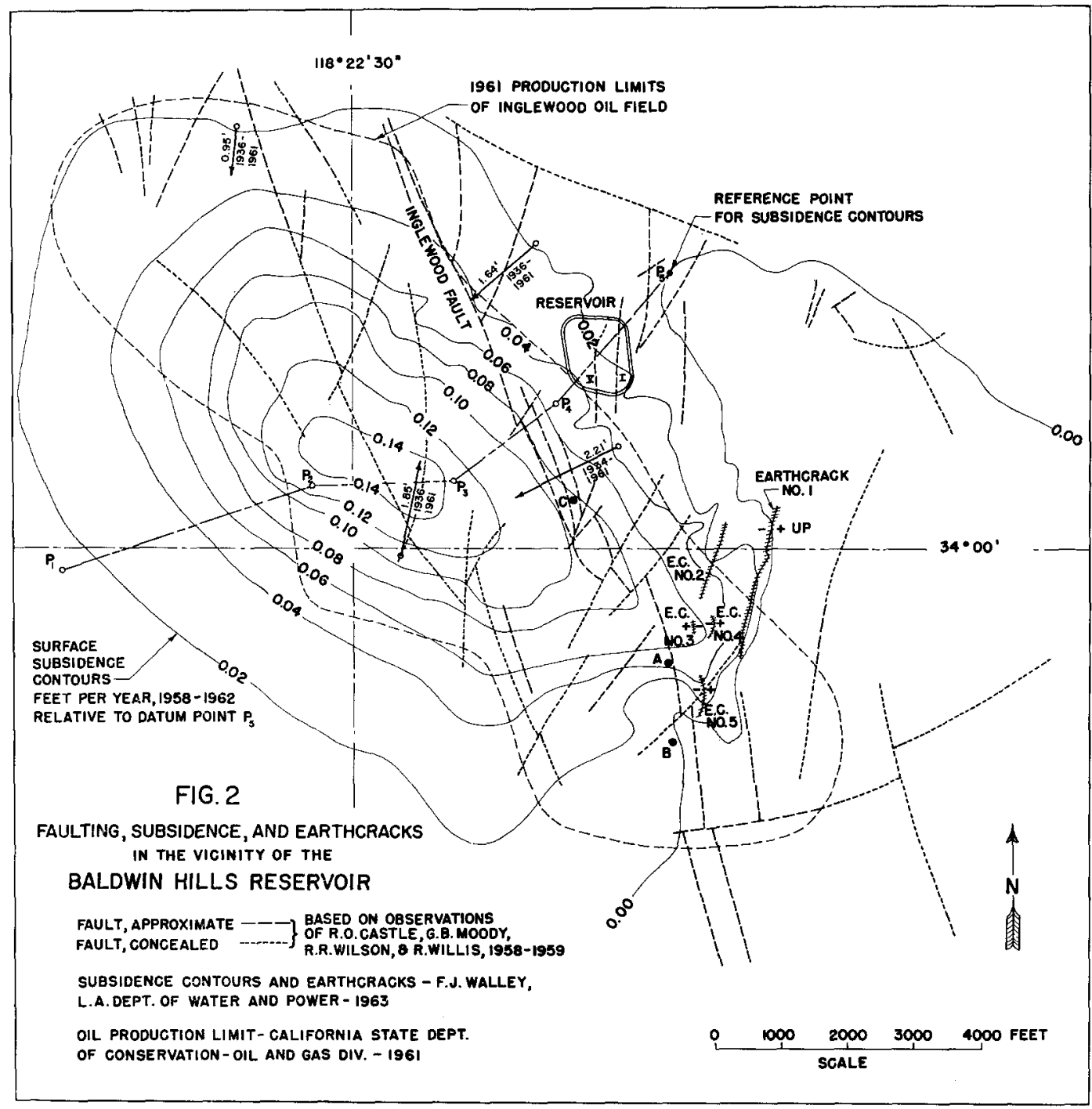

with the Palos Verdes formation near the crest, with the Inglewood formation for about $130 \mathrm{ft}$, and below that with the Pico formation. This interpretation of the local formations is not entirely consistent with that indicated in fig. 1, but reflects geologists' uncertainties in the details of the structure.

Tension and some shear joints are common in both the Pico and the Inglewood formations (Wilson, 1949). 
The fault running through the east side of the reservoir, marked I on fig. 2, was investigated in some detail during the excavation for the reservoir. At the center of the proposed reservoir, vertical motions of some $13 \mathrm{ft}$ were noted increasing to $26 \mathrm{ft}$ at the north side. Total horizontal movements could not be determined. It was not possible to determine the time at which these fault motions had occurred, but on the evidence of the appearance of the fault gouge and slicken-slides, the fault was termed active (Wilson, 1949).

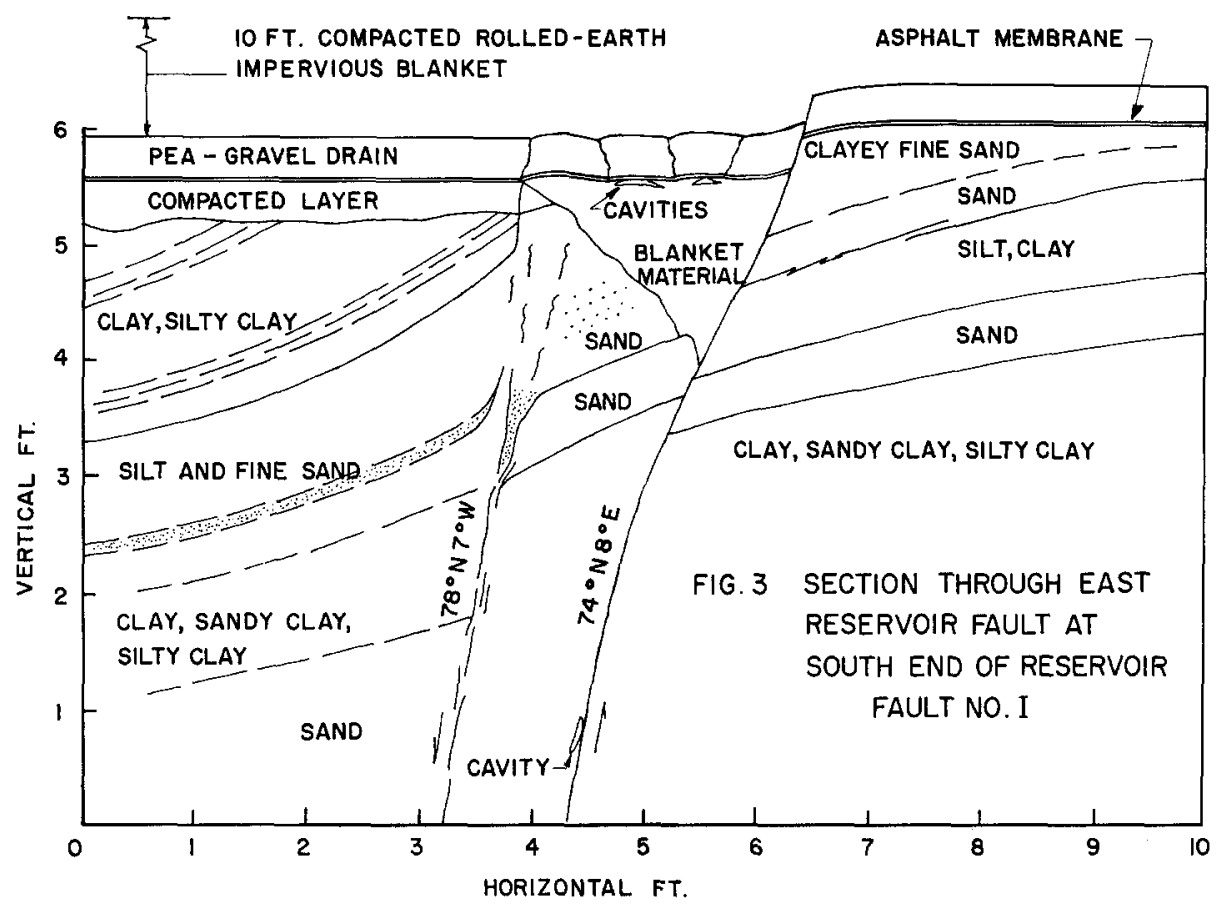

FIG. 3

Following the drainage of the reservoir during the failure, displacement along Fault No. I since the time of construction was made apparent by a crack running across the reservoir floor. In the course of the subsequent investigations, the fault zone was examined by trenching and tunneling to a depth of about $45 \mathrm{ft}$ below the original reservoir floor. The vertical section of fig. 3 shows in some detail this reservoir Fault No. I. Since the completion of the reservoir in 1951, a total maximum vertical displacement of about 7 inches has occurred on Fault I and about 3 inches on Fault No. V (fig. 2) as evidenced by the relative displacement of the asphalt seal underneath the reservoir. (State Report, 1964)

\section{Time Scale of the Recent Fault Movements}

Although the examination of Fault I after the failure of the reservoir showed clearly the relative displacements that had occurred since the completion of the 
reservoir in 1951, it is difficult to ascertain the time at which the fault motions started or the rate at which they proceeded. In 1957 the reservoir was drained and cleaned; at that time there were no reports of visible cracks on the floor of the reservoir.

The most direct evidence bearing on the time-scale involved in the fault movements is that provided by the record of crack growth in the concrete drainage inspection chamber underneath the reservoir. This reinforced concrete gallery (fig. 4) was provided to carry the drainage system pipes coming from the floor of the reservoir through the fault zone to the base of the gate tower. In October of 1951, a $3 / 32$ in. crack was noted in the ceiling of this chamber in the region of the fault zone. Strain gage points were established across the crack, and readings were taken at monthly intervals. In February of 1958, a new crack appeared on the floor of the chamber on the other side of the fault zone, and this crack was similarly monitored. In January 1960, two new cracks developed in the concrete between the gate tower and the location of the original cracks.

Figure 4 shows the average of strain gage readings at the two ends of the ceiling crack at " $\mathrm{A}$ " plotted for the whole history of the crack. It should be noted that although the crack was wide enough before the reservoir failure so that the steel reinforcing bars in the concrete were visible, no leakage through the crack was reported prior to failure.

It will be seen from fig. 4 that the configuration of the two major cracks corresponds to the relative fault motions that are known to have occurred, and that the width of the cracks, the distance between them, and the size of the chamber are compatible with the observed magnitude of the local fault motions. The location of the fault shown in fig. 4 is of course only approximate, as a zone of faulting of perhaps several feet wide is undoubtedly involved.

In view of the above facts, it is likely that the record of crack growth of fig. 4 is at least a rough indication of the time behavior of the local fault motions. Although the movements of the section of the inspection chamber could be modified by such factors as consolidation of the material under the reservoir, the general compatibility of all of the measurements strongly suggests an approximate equivalence. This same conclusion as to the time scale of the fault motions is born out by investigations of the steel shell in the connector conduit between the tower and the circulator lines (State Report, 1964). From the location and amount of corrosion products at the slipped joints, it has been inferred that motions had been going on over a number of years.

Referring again to fig. 4 , it will be seen that the record is characterized by several rather abrupt jumps at points marked D, E, F, and G, for example, superimposed on a curve of continually increasing slope. There is also an indication of a definite change in the rate of crack development some time in 1957 and in 1961. As mentioned previously the reservoir was drained and cleaned in March 1957 at which time no evidence of major cracking on the floor of the reservoir was reported. This operation may have taken place just prior to the noticeable increase of crack growth 


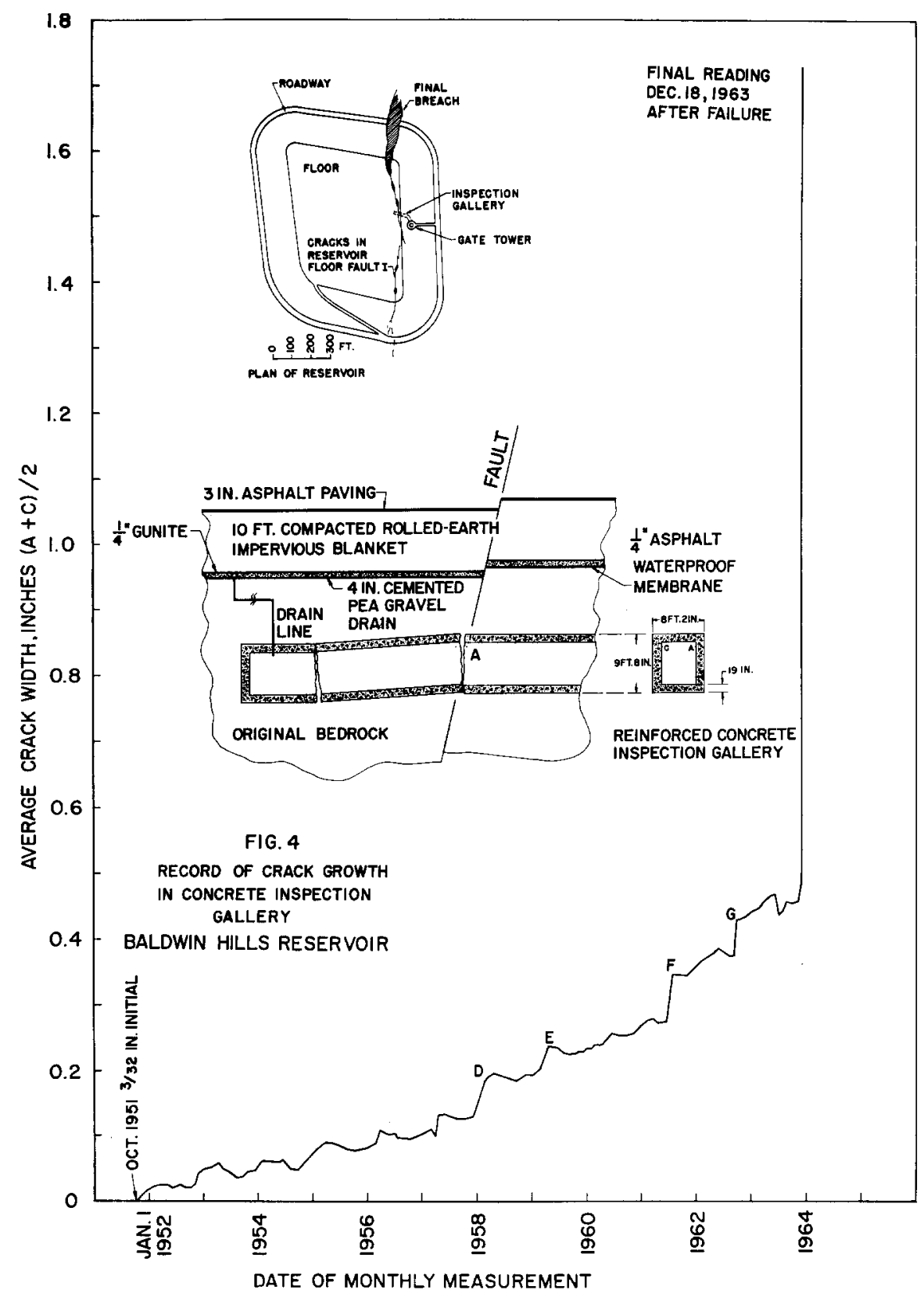

rate and was probably at a sufficiently early stage in the process that the fault motions had not penetrated through the $10 \mathrm{ft}$ thick rolled earth impervious blanket and the asphalt paving on the floor of the reservoir.

It will be observed that the crack growth curve of fig. 4 shows a pronounced yearly periodicity, with peaks occurring in the spring. This apparently does not correlate with any factors involved in the operation of the reservoir, such as water level. It 
is interesting to note that similar periodicities were found in ground level measurements in the Long Beach-Terminal Island-Wilmington region (Leypoldt, 1938).

\section{Crack Growth and Earthquakes}

Since the measurements of fig. 4 were taken only at monthly intervals, it is not possible to come to any conclusions about the abruptness of the fault motions at points such as D, E, F, and G. An examination was made of the earthquake records at the Seismological Laboratory of the California Institute of Technology in Pasadena to see if there was any correlation between these relatively sudden changes and the occurrence of earthquakes in the Baldwin Hills area. It might be expected either that a sudden motion at the fault could be triggered by the ground shaking induced by a nearby earthquake, or that the fault motion itself might generate the

TABLE I

Earthquakes Originating in the Baldwin Hills Area During Periods of Rapid Fault Motion (Fig. 4)

\begin{tabular}{c|l|l|c|c|c}
\hline $\begin{array}{c}\text { Fig. } \\
\text { Interval }\end{array}$ & \multicolumn{1}{|c|}{ Date of Rapid Movement* } & Date of Earthquake & $\begin{array}{c}\text { Magni- } \\
\text { tude }\end{array}$ & $\begin{array}{c}\text { Epicentral } \\
\text { Distance from } \\
\text { Reservoir Miles }\end{array}$ & $\begin{array}{c}\text { Accuracy of } \\
\text { Epicenter } \\
\text { Miles }\end{array}$ \\
\hline D & Dec. 9, 1957-Feb. 17, 1958 & Jan. 2, 1958 & 1.6 & 1 & 10 \\
E & Feb. 10, 1959-Mar. 13, 1959 & Feb. 22, 1959 & 1.4 & 12 & 10 \\
& & Feb. 27, 1959 & 1.7 & 14 & 10 \\
F & June 16, 1961-July 14, 1961 & July 5, 1961 & 2.4 & 18 & 3 \\
G & Aug. 29, 1962-Sept. 26, 1962 & Sept. 1, 1962 & 3.0 & 4 & 3 \\
\hline
\end{tabular}

* Observations of crack widths were made on dates given. It is not known when the movements occurred within this time interval.

$\dagger$ Epicenter location probably within given number of miles. Focal depths not accurately known.

earthquake. It is thus possible under various conditions to suppose that an earthquake is either the cause or the effect of a fault motion.

In table $I$ are listed the earthquakes originating near the reservoir within the monthly intervals during which the jumps at D, E, F, and G occurred. For D, a very small earthquake quite near the reservoir was recorded. For $\mathrm{E}$ and $\mathrm{F}$, however, the only earthquakes recorded in Pasadena are very small ones located 12, 14, and 18 miles from the reservoir, and hence it is not likely that they are connected in any way with the reservoir faults. For point $G$, a magnitude 3 earthquake is recorded within some 4 miles of the reservoir. The correlation of fault movement and earthquakes is thus seen to be dubious, a conclusion which is borne out by a relatively long list of small earthquakes close to the reservoir which do not appear to be connected with any special features on the crack growth curve of fig. 4. These earthquakes are listed in table II. The last two earthquakes in table II are of special interest since damage occurred in the Inglewood Oil Fields which was apparently associated with both these earthquakes (State Report, 1964). In fig. 2, the points marked $\mathrm{A}$ and $\mathrm{B}$ locate two oil wells reported damaged by the earthquake of February 18, 1963, and C locates a well reported damaged by the March 10, 1963 
earthquake. It will be noted from fig. 4 that no special features are present in the crack growth curve to correspond with these two earthquakes.

\section{Additional Farthquake Investigations}

To investigate possible seismic effects associated with the final break in the reservoir embankment on December 14, 1963, a careful examination of the seismo-

\section{TABLE II}

Earthquakes Originating in thi Baldwin Hills and Vicinity for which there is no Correlation with Rapid Fault Motion (fig. 4)

\begin{tabular}{|c|c|c|}
\hline Date of Earthquake & Magnitude & $\begin{array}{l}\text { Epicentral Distance } \\
\text { from Reservoir, Miles }\end{array}$ \\
\hline 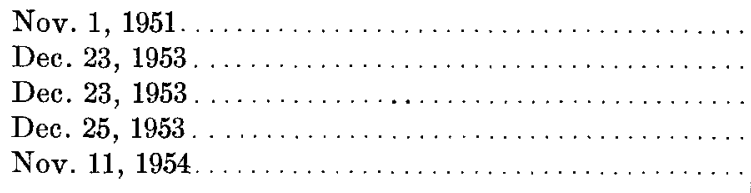 & $\begin{array}{l}2.5 \\
2.7 \\
2.8 \\
2.8 \\
2.3\end{array}$ & $\begin{array}{l}2 \\
3 \\
3 \\
3 \\
5\end{array}$ \\
\hline 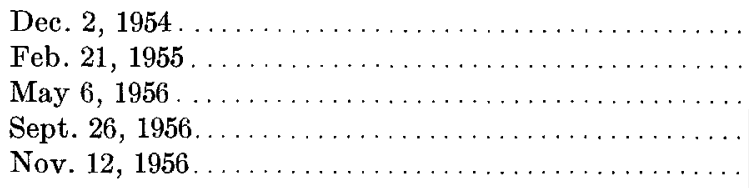 & $\begin{array}{l}2.1 \\
3.1 \\
2.3 \\
2.5 \\
2.4\end{array}$ & $\begin{array}{l}4 \\
2 \\
2 \\
6 \\
4\end{array}$ \\
\hline 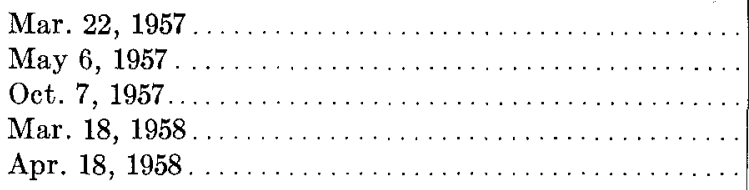 & $\begin{array}{l}2.2 \\
1.8 \\
1.7 \\
1.7 \\
2.5\end{array}$ & $\begin{array}{l}1 \\
5 \\
2 \\
3 \\
4\end{array}$ \\
\hline 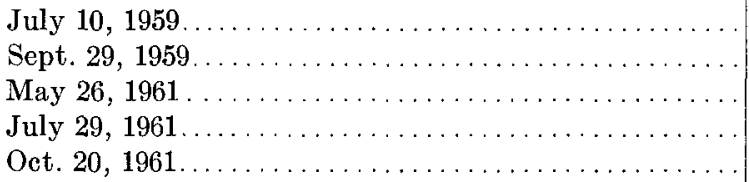 & $\begin{array}{l}2.5 \\
2.2 \\
2.5 \\
2.7 \\
4.1\end{array}$ & $\begin{array}{r}5 \\
6 \\
6 \\
6 \\
30\end{array}$ \\
\hline 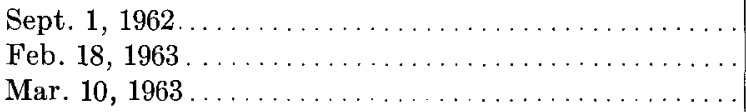 & $\begin{array}{l}3.0 \\
3.4 \\
3.0\end{array}$ & $\begin{array}{r}4 \\
6 \\
17\end{array}$ \\
\hline
\end{tabular}

grams from the Pasadena station was made for several days prior to the break, the day of the break, and for several subsequent days. The Seismological Laboratory of the California Institute of Technology in Pasadena, located about 15 miles from the reservoir, is the nearest permanent seismological station provided with $24 \mathrm{hr} /$ day recording seismographs. The sensitivity of these instruments is such that any seismic disturbance of significance for the safety of the reservoir would be recorded in Pasadena. The only seismic events that might conceivably be missed in Pasadena would be very small earthquakes in the immediate vicinity of the reservoir, which, while they could have no effect on the reservoir, might have some importance in a general study of the local seismicity of the region and its relationship to the details 
of the local fault structure. No events were detected on the Pasadena seismograms that seemed likely to have any connection with the reservoir fault movements, or with the final failure.

After the failure, a portable Benioff type continuous recording seismograph was set up at the reservoir site to record local conditions. It was thought that if the local tectonic movements were in any way associated with seismic activity, such activity would very probably continue after the failure. It was known from previous work that this area in the Los Angeles Basin is a particularly noisy one, with an unusually high microseismic background (Gutenberg, 1957). In order to suppress these background disturbances, the equipment was operated at a low magnification of the order of 1000 . Over an operating period of several weeks, no significant local seismic events were observed which seemed likely to have any connection with fault movements.

On several occasions during the life of the reservoir, reports were made to engineers at the Department of Water and Power (D. W. P.) by D. W. P. personnel at the Baldwin Hills Reservoir that earthquakes had been felt at the site. Subsequent checks showed that some of these earthquakes had not been recorded in Pasadena. This suggests the existence of very local shocks, a study of which might throw some light on local tectonic processes. It would certainly be desirable in such cases to operate a continuously recording seismograph at the site to provide the means for long-term research investigations.

In October 1961, two strong-motion earthquake recorders were installed at the reservoir by the Department of Water and Power to indicate the maximum value of strong earth shaking, should it occur. These seismoscopes are relatively insensitive instruments, and would give a reading only in the presence of heavy shaking such as might accompany a large nearby earthquake. The record plates of these instruments had been periodically examined since installation, and were again examined after the failure. There was no indication from these records that the reservoir had been subjected to any heavy shaking since the 1961 installation date. It is interesting to note that although one of the seismoscopes was within $300 \mathrm{ft}$ of the final break in the embankment, through which a large turbulent flow of water rushed during failure, no measurable vibrations were recorded.

\section{Seismicity of the Baldwin Hills}

As one means of evaluating the general seismicity of the Baldwin Hills Area, an epicenter map of past earthquakes was prepared for a region of some $30 \times 35$ miles centered on the reservoir. This compilation was much facilitated by a new Catalog of Southern California Earthquakes prepared by Richter, Allen, Nordquist, and St. Amand on I.B.M. punched cards (Nordquist, 1964). Using this catalog, it is possible to program a digital computer to compile such data as location, depth, magnitude, and quality of data, for all shocks of a specified size within a specified distance of a prescribed point. Figure 5 shows the results for earthquakes occurring within the dates of January 1, 1934 to May 31, 1963. Within the accuracy of the epicenter location, the map reveals essentially a uniform distribution of epicenters throughout, the area. The tendency to line up on coordinate axes is, of course, a consequence of rounding off the coordinate values. It is evident that there is no detailed correspondence between the epicenter locations and known fault locations. If the ac- 
curacy of hypocenter locations could be improved to justify a three-dimensional plot, it is likely that some better correlations would be found between the points of origin of the earthquakes and the fault system. A study has recently been made of fault details, based on precise location of hypocenters obtained from a relatively

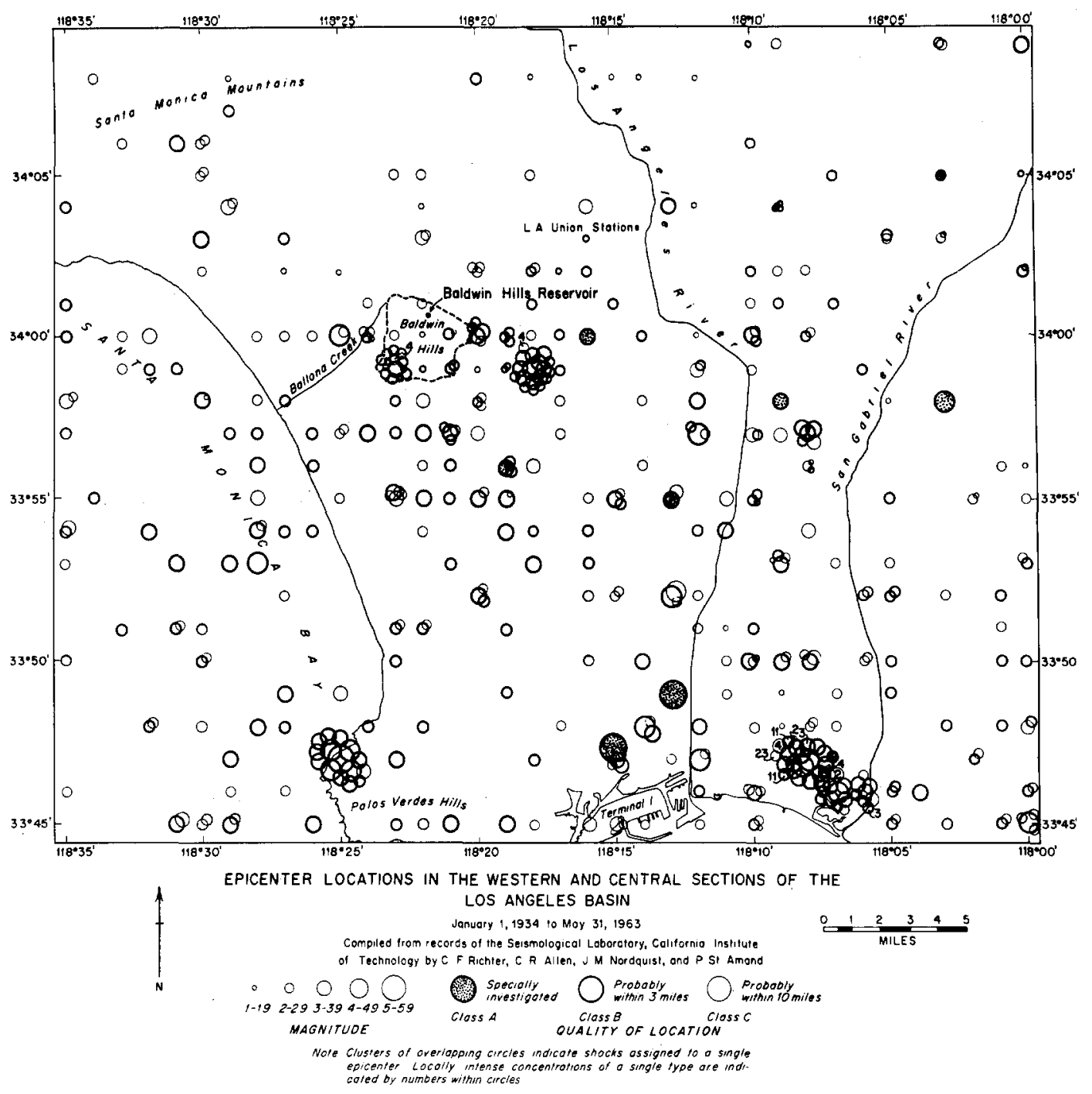

FIG. 5

dense network of portable stations, which seems to offer hope for such improved correlations (Cisternas, 1963).

\section{Comparison with Other Fault Motion Situations}

It is of interest to compare the type of fault motions evidently involved at Baldwin Hills with other recorded cases. Only two other instances are known for which time records of relatively slow fault motions have been obtained. 
The first of these was measured across the surface trace of an active overthrust fault in the Buena Vista Hills, Kern County, California (Wilt, 1958). It was first noted in 1932 that oil wells were being sheared off by a fault for which a surface fault scarp was located. In 1933, stakes were set across the fault scarp to establish measuring points, and in 1952, these stakes were replaced by 2 in. pipes set in concrete. Tape measurements corrected for temperature were used. From 1933 to 1958, a total relative movement on the fault plane parallel to the dip of about $1.6 \mathrm{ft}$ has occurred. This movement has been approximately uniform, with a slight tendency to a decreasing rate. This Buena Vista fault is located almost 25 miles from the epicenter of the July 21, 1952 magnitude 7.7 Kern County Earthquake. Fault measurements were made 48 days prior to the earthquake, and 50 days after the earthquake, after the major aftershocks had subsided. In addition, Wilt was able to be at the site just 10 minutes after the main shock to observe that there was no surface movement at the fault scarp during the earthquake. The plot of accumulated fault motion does indicate a relatively abrupt change of slope, corresponding to the Kern County Earthquake, but this is only a minor factor accounting for perhaps $0.03 \mathrm{ft}$ out of the total of $1.6 \mathrm{ft}$.

A second interesting case of slow fault motion is occurring along the main San Andreas fault at the W. A. Taylor Winery near Hollister, California. In this case, the main trace of a horizontal fault movement passes directly through the concrete walls and floor slab of a building, which is being slowly pulled apart by the movements (Steinbrugge and Zacher, 1960). Several special creep recorders with $3 \mathrm{ft}$ gage lengths were installed at the site in 1957 and 1958, and a record of accumulated strain has thus been obtained (Tocher, 1960). From July 9, 1958 to March 8, 1960, a total relative horizontal displacement of 1.1 in. has occurred across the crack on the floor slab. The time record of this motion looks much like the first portion of that shown in fig. 4, with most of the motion accounted for by four abrupt jumps superimposed on a steady drift. Only one of the jumps seemed to correlate with local seismic activity, having occurred at the same time as a sharp local earthquake of magnitude 5.0 located about 4 miles from the recording point. The total relative motions measured at the winery are consistent with these established by precise geodetic measurements made locally in the area (Whitten and Claire, 1960).

At least one other case has been reported in the literature of a fault motion apparently occurring without an associated seismic disturbance having been detected (Hill, 1954). In 1949, a movement of a few inches took place along the surface trace of a fault on the east side of the San Joaquin Valley about 8 miles north of Bakersfield. A disturbed zone was followed for a distance of some 2 miles. No seismic activity in that area was reported from the Pasadena or Berkeley Seismological Stations for the date of the movement.

\section{Causes of Fault Motion}

Among the factors which may be closely connected with the reservoir fault motions are: (a) general tectonic movements of the earth's crust in the Los Angeles Basin; (b) soil and water loads of the reservoir itself; (c) local subsidence in the Baldwin Hills Area.

As indicated above, both the geological investigations of the Inglewood Fault System and the studies of local seismicity have shown clearly that the Baldwin 
Hills area has been, and is, a very active region tectonically. Additional evidence for general crustal movements is afforded by studies of elevation changes in the Los Angeles Basin (Grant and Sheppard, 1939). Precision levels run by the Bureau of Engineering of the City of Los Angeles have shown that several areas in the basin are undergoing downward movement, and that at least one region, 2-3 miles south of the Baldwin Hills, has recently been rising at a maximum rate of 0.03 feet per year. On the evidence of the accuracy of the survey, which was tied in with tidal bench marks at San Pedro, Grant and Sheppard conclude that the elevation change would probably be ascribed to tectonic causes associated with the Newport-Inglewood zone of flexure. Although the details of these tectonic effects cannot be worked out with the available data, elevation changes on a large scale are evidently still continuing in the area.

Turning to more local effects, the most striking elevation changes in the vicinity of the reservoir are those associated with a subsidence bowl just adjacent to the reservoir. Although local elevations have been modified to some extent by the soil and water loads imposed by the reservoir itself, these factors as well as the abovementioned tectonic movements are evidently small compared with the whole subsidence bowl pattern, which will now be examined in some detail.

\section{The Baldwin Hulus Subsidence Zone}

The solid contours of fig. 2 define the pronounced local subsidence bowl which coincides roughly with the Inglewood Oil Field ("California Oil Fields", 1961). These contours are based on measurements made by the Department of Water and Power of the City of Los Angeles (Walley, 1963). Similar maps have been prepared by the Los Angeles County Engineer, and by the Geodetic Section, Survey Division, Bureau of Engineering, of the City of Los Angeles. The maps from these three sources vary slightly because they include different time intervals, are perhaps based on different reference points, and presumably involve some independent measurements, but the general features are all very similar.

The earliest accurately surveyed benchmarks in the area were established in 1917 by the Department of Water and Power at the site of the proposed Centinela reservoir, about $3000 \mathrm{ft}$ southwest of the Baldwin Hills reservoir. In 1939, the preliminary surveys were made for the Baldwin Hills reservoir, and benchmarks were established and tied into U.S. Coast and Geodetic Survey reference points. Since that time, periodic careful resurveys have built up an accurate picture of the subsidence pattern (Walley, 1963). On the basis of these measurements made from 1917 through 1963, it seems that the center of the subsidence bowl has dropped with respect to the edges during that period by about $9 \mathrm{ft}$ (State Report, 1964). Although there is a considerable gap in the elevation measurements from 1917 to the 1940's, the above estimate of the total maximum local subsidence should be correct within 1 to 2 feet.

In fig. 6 is shown a vertical cross-section through the reservoir along the line $P_{1}$, $P_{2}, \cdots P_{5}$ of fig. 2, which passes approximately through the center of the subsidence bowl (Walley, 1963). It will be noted that the reservoir is located on the subsidence profile in such position as to be subject to tension. This is further established by repeated measurements of the dimensions of the reservoir, which show that 
there has been an elongation of the NE-SW diagonal of about $0.4 \mathrm{ft}$ between 1950 and 1963 (State Report, 1964).

Studies have also been made of horizontal movements in the Baldwin Hills region. On fig. 2 are shown horizontal movement vectors for several points for the time intervals marked, based on measurements of the Survey Division, Department of the County Engineer, Los Angeles County (Alexander, 1962). These horizontal movements are seen to be consistent with the picture of the subsidence as indicated by the elevation rate of change contours. A very similar pattern of horizontal movements has been measured at the Buena Vista Hills area, in the region of the slowly moving overthrust fault previously mentioned (Whitten, 1961).

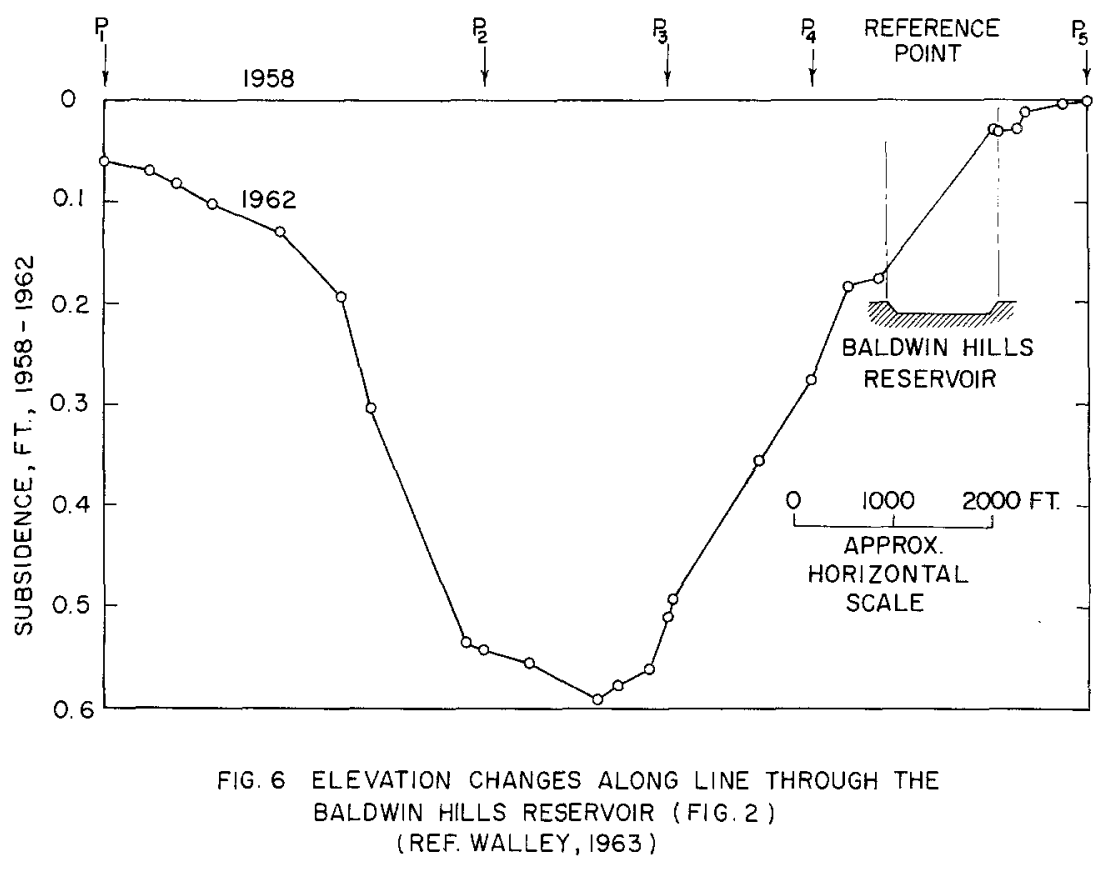

Related to the whole subsidence pattern in the Baldwin Hills are a number of earth cracks that have been observed since 1957. On fig. 2 are marked several of these cracks which have caused considerable damage to streets and paved areas during the past few years. These cracks, which involve some vertical offset but no observed horizontal displacements, evidently occur in regions where the rate of subsidence is rapidly changing over short distances (State Report, 1964).

\section{Comparison with the Long Beach-Terminal Island Subsidence}

The subsidence pattern at Baldwin Hills resembles in many respects the wellknown situation in the Long Beach-Terminal Island-Wilmington area, and it is instructive to compare the two regions. The conditions at Long Beach have been extensively studied since the early 1940's, and have been described in detail in a number of publications (Gilluly and Grant, 1949; Grant, 1954; Steinbrugge and Bush, 1958). 
At Long Beach, the subsidence bowl is elliptical in shape, with dimensions of about $35,000 \mathrm{ft}$ by $23,000 \mathrm{ft}$. The total maximum subsidence in the center during the period 1928-1962 is about 28 feet. Comparing this with the dimensions of the Baldwin Hills bowl, which is roughly elliptical with dimensions of $14,000 \mathrm{ft}$ by $10,000 \mathrm{ft}$, and a total maximum subsidence during 1917-1963 of about $9 \mathrm{ft}$, it will be seen that the proportions of the deformed regions are quite similar. Horizontal measurements made at Long Beach indicate horizontal ground movements as high as $9 \mathrm{ft}$ since 1937 , the general pattern being towards the center of the subsidence bowl, similar to the horizontal movements indicated by the vectors of figure 2 .

\section{Seismic Activity in the Long Beach Subsidence Region}

A number of local earthquakes have occurred in the Long Beach subsidence zone, and have caused considerable damage to oil wells (Frame, 1952). These earthquakes have been studied by Richter, who observed that the seismograms recorded in Pasadena had a number of peculiarities, such as an unusually large development of long-period motion, and a lack of sharpness in the beginning of the motion (Richter, 1958). These features can apparently be attributed to fracturing along nearly horizontal bedding planes at a depth of about $1700 \mathrm{ft}$, the causative stresses being those associated with the local subsidence. The long-period motions could thus be explained as surface waves resulting from the unusually shallow depth of focus, and the relatively gradual beginning by the nature of the slipping which is perhaps a considerably slower event than the breaking of rocks for more normal tectonic earthquakes. An earthquake of this special type had also occurred during the aftershock activity of the Long Beach earthquake of 1933, along with many other small shocks of a normal type. This 1933 earthquake, of course, was considerably before the development of a pronounced subsidence bowl in the area, so that these special type earthquakes can apparently also be generated by tectonic stresses. Earthquakes of this special type occurred in the subsidence region in 1947, 1949, 1951, and 1955. The earthquake of November 17, 1949 was felt in Long Beach by a few persons, and some 200 oil wells went out of production, some of them permanently. The damage was associated with horizontal shearing motion, with relative displacements of the order of 1 foot.

There have been at least two small subsurface displacements in the Inglewood fault zone in recent years $(1941,1944)$ which damaged oil wells, but which were apparently triggered by a normal earthquake in the vicinity (Richter, 1958). Perhaps of a similar nature are the two recent earthquakes mentioned above (February 18, 1963 and March 10, 1963) which damaged oil wells near the Baldwin Hills reservoir, and were apparently of the normal type.

\section{CONCLUSIONS}

The fault motions at the Baldwin Hills Reservoir have apparently been progressing at a relatively slow rate over a period of some 10 years, prior to a possibly larger motion at the time of the reservoir failure, and they are similar in many respects to other slow fault movements reported elsewhere. As far as damage to structures and engineering works is concerned, such slow fault motions pose problems completely different from those associated with the more common rapid-fault-motion generated 
earthquake. It is very likely that as more detailed explorations and studies are undertaken in regions of active earth movement, it will be found that such slow fault motions are not uncommon. It is evident that designers of engineering works will need to have an increased understanding of such phenomena if they are to prepare safe and economical designs for such regions.

\section{ACKNOWLEDGMENTS}

As members of the Board of Inquiry appointed by the Mayor of the City of Los Angeles to investigate the failure of the Baldwin Hills Reservoir, the authors enjoyed the fullest cooperation of all members of the Department of Water and Power. The opinions expressed in this paper, however, are those of the authors. In particular, we would like to thank Mr. R. R. Wilson, Mr. H. B. Hemborg, and Mr. W. J. Simon of the Department of Water and Power, for assistance in the collection of data. Dr. Frank Press of the Seismological Laboratory of the California Institute of Technology made available the portable seismograph for the Baldwin Hills site, as well as the seismological records of past earthquakes. Thanks are expressed also to Professor C. F. Richter of the Seismological Laboratory and Professor C. R. Allen of the Division of Geological Sciences, California Institute of Technology, who made valuable suggestions on seismological and geological matters, and to Mr. J. M. Nordquist of the Seismological Laboratory for assistance with the seismicity map.

\section{References}

Alexander, Ira $\mathrm{H}$.

1962. "Horizontal Earth Movement in the Baldwin Hills, Los Angeles Area," Jour. Geophys. Res., Vol. 67, No. 6, June.

Castle, R.O.

1960. "Geologic Map of the Baldwin Hills Area, California," U.S. Geological Survey, Open File Report.

Cisternas, Armando,

1963. "Precision Determination of Focal Depths and Epicenters of Local Shocks in California," Bull. Seis. Soc. Amer., Vol. 53, No. 5, Oct.

Driver, Herschel L.,

1943. "Inglewood Oil Field," Bull, 118, Dept. of Natural Resources, State of California.

Frame, R. G.,

1952. "Earthquake Damage, its Cause and Prevention in the Wilmington Oil Field," California Oil Fields, Vol. 38, No. 1, Department of Natural Resourees, State of California, San Francisco.

Gilluly, James, and Grant, U. S.,

1949. "Subsidence in the Long Beach Harbor Area, California, "Bull. Geol. Soc. Amer., Vol. 60, March.

Grant, U. S.,

1954. "Subsidence of the Wilmington Oil Field, California," Geology of Southern California (R. H. Jahns, ed.), Bulletin 170, Division of Mines, Department of Natural Resources, State of California, San Francisco.

Grant, U. S., and Sheppard, N. E.,

1939. "Some Recent Changes in Elevation in the Los Angeles Basin of Southern California and their Possible Significance," Bull. Seis. Soc. Amer., Vol. 29, No. 2, April.

Gutenberg, B.,

1957. "Effect of Ground on Earthquake Motion," Bull. Seis. Soc. Amer., Vol. 47, No. 3, July.

Hill, Mason L.,

1954. "Tectonics of Faulting in Southern California," Geology of Southern California (R. H. Jahns, ed.), Bulletin 170, Division of Mines, Department of Natural Resources, State of California, San Francisco. 
Leypoldt, Harry,

1938. "Periodicity of Earth Movements in Los Angeles Harbor," Bull. Seis. Soc. Amer. Vol. 28, No. 1.

Nordquist, John M.,

1964. "A Catalog of Southern California Earthquakes, and Associated Electronic Data Processing Programs," Bull. Seis. Soc. Amer., Vol. 54, No. 3, June.

Richter, Charles F.,

1958. Elementary Seismology, W. H. Freeman \& Company, San Francisco.

Steinbrugge, Karl V., and Zacker, Edwin G.,

1960. "Creep on the San Andreas Fault-Fault Creep and Property Damage," Bull. Seis. Soc. Amer. Vol. 50, No. 3, July.

Steinbrugge, Karl V., and Bush, Vincent R.,

1958. "Subsidence in Long Beach-Terminal Island-Wilmington, California," Pacific Fire Rating Bureau, March.

Tocher, Don,

1960. "Creep on the San Andreas Fault-Creep Rate and Related Measurements at Vineyard, California," Bull. Seis. Soc. Amer., Vol. 50, No. 3, July.

Walley, F. J.

1963. "Report on Elevation Changes of Bench Marks and Land Subsidence in the Baldwin Hills Reservoir Area," Dept. of Water \& Power, City of Los Angeles, Sept.

Whitten, C. A.,

1961. "Measurement of Small Movements in the Earth's Crust," Annales Academiae Scientiarium Fennicae, Series A, III, Geologia-Geographia 61, Helsinki.

Whitten, C. A., and Claire, C. N.,

1960. "Creep on the San Andreas Fault-Analysis and Geodetic Measurements Along the San Andreas Fault," Bull. Seis. Soc. Amer., Vol. 50, No. 3, July.

Wilson, R. R.,

1949. "Geology of the Baldwin Hills Reservoir Site and Immediate Vicinity," Field Engineering Division, Water System, Department of Water \& Power, City of Los Angeles, February.

Wilt, James W.,

1958. "Measured Movement Along the Surface Trace of an Active Thrust Fault in the Buena Vista Hills, Kern County, California," Bull. Seis. Soc. Amer., Vol. 48, No. 2, April.

Woodford, A. O., Schoelhamer, J. E., Vedder, J. G. and Yerkes, R. F.,

1954. "Geology of the Los Angeles Basin," Geology of Southern California, (R. H. Jahns, ed.), Bulletin 170, Division of Mines, Department of Natural Resources, State of California, San Francisco.

1961. "California Oil and Gas Fields," Pt. 2, Division of Oil \& Gas, State of California, San Francisco, (Inglewood Oil Field).

1964. "Investigation of Failure-Baldwin Hills Reservoir," Department of Water Resources, State of California, April.

Division of Engineering and Applied Science

California Institute of Technology

Pasadena, California

Manuscript received September 16, 1964. 